\title{
An Anatomical Study of Prune Brown Line Disease and Immuno-localization of Tomato Ringspot Virus in Plum Bark
}

\author{
K. V. Kommineni, Graduate Research Assistant, and D. C. Ramsdell, Professor, Department of Botany and Plant \\ Pathology, Michigan State University, East Lansing 48824
}

\begin{abstract}
Kommineni, K. V., and Ramsdell, D. C. 1997. An anatomical study of prune brown line disease and immuno-localization of tomato ringspot virus in plum bark. Plant Dis. 81:855-861.

Bark from the graft union of tomato ringspot virus (ToRSV) infected plum, symptomatic for brown line disease, showed anatomical changes characteristic of the wound response process. The wound tissue consisted of necrotic cells demarcated by pinkish purple necrophylactic periderm, whose function is to protect living tissues from detrimental effects associated with necrosing cells. However, formation of gray exophylactic periderm led to the sloughing off of the wound tissue and the necrophylactic periderm, resulting in discontinuity of the exophylactic periderm and secondary virus invasion into the wound site. The changes seen in the bark suggest that the hypersensitive response in plum rootstock bark to ToRSV is slow, allowing a systemic movement of the virus and development of a brown line (BL) along the scion and rootstock union. Necrophylactic periderm was not seen in the bark from the graft union of a healthy plum tree. In the graft union of a plum tree without a BL, but testing ToRSV-positive in the roots, localized areas of wound tissue with pinkish purple necrophylactic periderm developed only in the rootstock portion of the tree. Silver-enhanced protein A-colloidal gold immunolabeling was seen on the cell wall and in the cytoplasm of bark tissue from the BL region of scion and rootstock and leaves from the rootstock suckers.
\end{abstract}

Thousands of plum and prune trees, even entire orchards, have been lost to tomato ringspot nepovirus (ToRSV), the causal agent of prune brown line (PBL) disease in prune and plum trees $(3,6,12,14)$. The disease is diagnosed by the presence of a brown line (BL) in the bark at the graft union of affected trees (9). The brown line is a result of the necrosis of the phloem and cambial tissue, reportedly triggered by the hypersensitive response of the scion to ToRSV infection in a susceptible rootstock (6). Other symptoms associated with PBL include an overgrowth of the scion at the graft union leading to a constricted appearance of the rootstock, yellowing of the leaves, stem pitting at the graft union, and susceptibility to winter injury $(2,7)$. Testing of the rootstock bark and sucker leaves of Prunus spp. by enzyme-linked immunosorbent assay (ELISA) demonstrated the presence of ToRSV in these tissues (3). The virus was detected in the scion bark tissue in two out of 32 PBLaffected trees when samples were taken close to the BL (3). An anatomical study of the bark at the BL and immuno-localization of the virus in plum bark has not pre-

Corresponding author: D. C. Ramsdell

E-mail: ramsdell@pilot.msu.edu

Accepted for publication 6 May 1997.

Publication no. D-1997-0612-01R

(C) 1997 The American Phytopathological Society viously been done. One objective of this research was to study the anatomical changes in the bark at the BL region in an effort to understand the progress of the disease and the associated changes at the graft union compared with a healthy graft union. A second objective of the study was to localize the virus coat protein with confocal light microscopy-immunogold labeling in (i) the rootstock sucker leaf tissue and (ii) bark from the BL region of the rootstock and scion.

\section{MATERIALS AND METHODS}

A field plot consisting of five different rootstock and five plum cultivar combinations of 2-year-old trees was established on fumigated ground in the summer of 1993 at the Northwest Regional Horticultural Research Station in Traverse City, Michigan. One hundred trees in the virus-treated block were slash-inoculated below the graft union with a razor blade dipped in purified (16) ToRSV $(0.5 \mathrm{mg} / \mathrm{ml})$. Another 100 trees in the control block were mockinoculated using buffer only. Sixteen virusinoculated trees had developed BL disease by September 1996. Bark samples from the graft union of BL diseased and noninoculated control trees were collected and immersed immediately in a solution of $3 \%$ (wt/vol) paraformaldehyde in $0.05 \mathrm{M}$ phosphate buffer, $\mathrm{pH}$ 7.0. For the anatomical study, samples were obtained from the following diseased and healthy scion/ rootstock combination trees: 70031/Marianna 4001, 70031/Myrobalan 29C, and Stanley/
Myrobalan 29C. Thick sections (20 to 30 $\mu \mathrm{m})$ obtained using a sliding microtome were mounted in $50 \%$ ( $\mathrm{vol} / \mathrm{vol}$ ) glycerol in water. Specimens were stained with Sudan IV $(1 \%$ [wt/vol] Sudan IV in $70 \%$ ethanol in water) to confirm the presence of the periderm and to detect suberized cells in the brown line region.

For the immunolabeling study, samples of the $\mathrm{BL}$ region and also the rootstock and scion tissue immediately adjacent to the BL of a 70031/Marianna 4001 and a Valor/St. Julian 655-2 plum tree were dehydrated in a graded series of ethanol concentrations and embedded in LR White following standard procedures (17). Semithin sections, 1 to $1.5 \mu \mathrm{m}$, were cut with a glass knife on an ultramicrotome (Reichert Ultracut, Reichert Corp., Buffalo, NY). Additionally, rootstock bark and sucker leaf samples from virus-infected Stanley/ Myrobalan 29C plum trees that had yet to develop a BL and were part of a greenhouse-based inoculation study were also fixed and processed as above for immunolabeling. The rootstock bark tissue from an uninoculated Stanley/Myrobalan 29C tree served as a negative control.

Immunogold labeling for light microscopy. Production of ToRSV antiserum. Purified (16) ToRSV $(0.3 \mathrm{mg})$ in $1.0 \mathrm{ml}$ of $0.05 \mathrm{M}$ phosphate buffer was mixed with $1.0 \mathrm{ml}$ of Freund's incomplete adjuvant to form an emulsion. The emulsion was injected subcutaneously into a New Zealand White female rabbit. The rabbit was given second and third booster injections at 1week intervals with 0.13 and $0.5 \mathrm{mg}$ of ToRSV, respectively. All injections were done with emulsions prepared in Freund's incomplete adjuvant. Test bleeds were done at 4 and 5 weeks after the first injection. Antiserum titers (1:512) were determined in Ouchterlony plates against twofold dilutions of purified ToRSV in $0.05 \mathrm{M}$ phosphate buffer, $\mathrm{pH}$ 7.0.

Protein A-gold labeling and silver enhancement. Semi-thin (1 to $1.5 \mu \mathrm{m}) \mathrm{sec}-$ tions were mounted on glass slides with a polyvinyl alcohol-vinyl trimethoxy silane 1:50 (vol/vol) adhesive (4) and cured overnight at $37^{\circ} \mathrm{C}$. The nonspecific antigenic sites on the sections were blocked for $1 \mathrm{~h}$ at room temperature (RT) with $0.01 \mathrm{M}$ Tris-buffered saline, $\mathrm{pH} 7.0$, and $10 \%$ (wt/vol) bovine serum albumin (TBSBSA). The sections were then incubated with ToRSV antiserum diluted 1:250 ( $\mathrm{vol} / \mathrm{vol}$ ) in TBS-BSA by inverting the 
slide onto the antiserum solution for $1.5 \mathrm{~h}$, RT. The sections were thoroughly rinsed (five times for $10 \mathrm{~min}$ each) with TBSBSA amended with $0.5 \%$ Triton X-100 and then labeled with protein A-gold $(10 \mathrm{~nm})$ (Amersham Life Sciences, Arlington Heights, IL) diluted 1:50 ( $\mathrm{vol} / \mathrm{vol})$ in TBSBSA for $1 \mathrm{~h}, \mathrm{RT}$, by inverting the slide onto the buffer surface. This was followed by four 10-min washes with TBS-T and four 10-min washes with double distilled water. The silver enhancement was done with the Intense-M kit (Amersham) for three 5-min exposures. The sections were then counterstained with $0.1 \%$ (wt/vol) aqueous Safranin-0 and mounted in $50 \%$ ( vol/vol) glycerol in water. Control tissue sections were always included on each slide along with the sections from the test blocks. Every labeling experiment was performed at least twice. The BL sections were also labeled with preimmune serum in the manner detailed above.

Analysis of the immunolabel with the laser scanning confocal microscope. Observations were made on a Zeiss 210 laser scanning confocal microscope using an argon ion laser $(514 \mathrm{~nm})$. A phase contrast and a corresponding confocal reflected image were collected for all samples. The images were line averaged and stored. The transmitted images were colored green, and the reflected images were colored red. The colored images were then overlaid with the reflected image on top of the transmitted image. Photographs of the overlaid images were recorded on color photographic film.

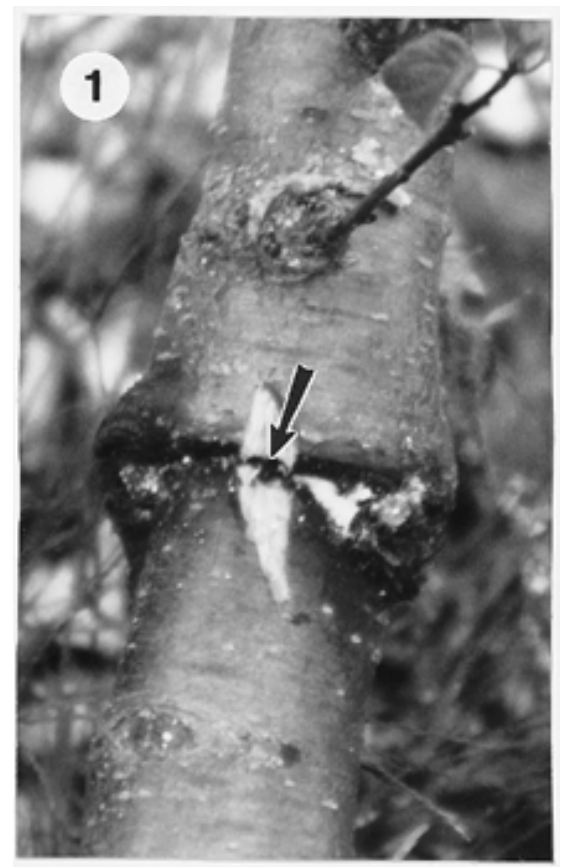

Fig. 1. Brown line (BL, arrow) at graft union of tomato ringspot virus-infected tree at the field plot in Traverse City, Michigan. Bark at graft union was removed to expose underlying woody cylinder and BL symptom.
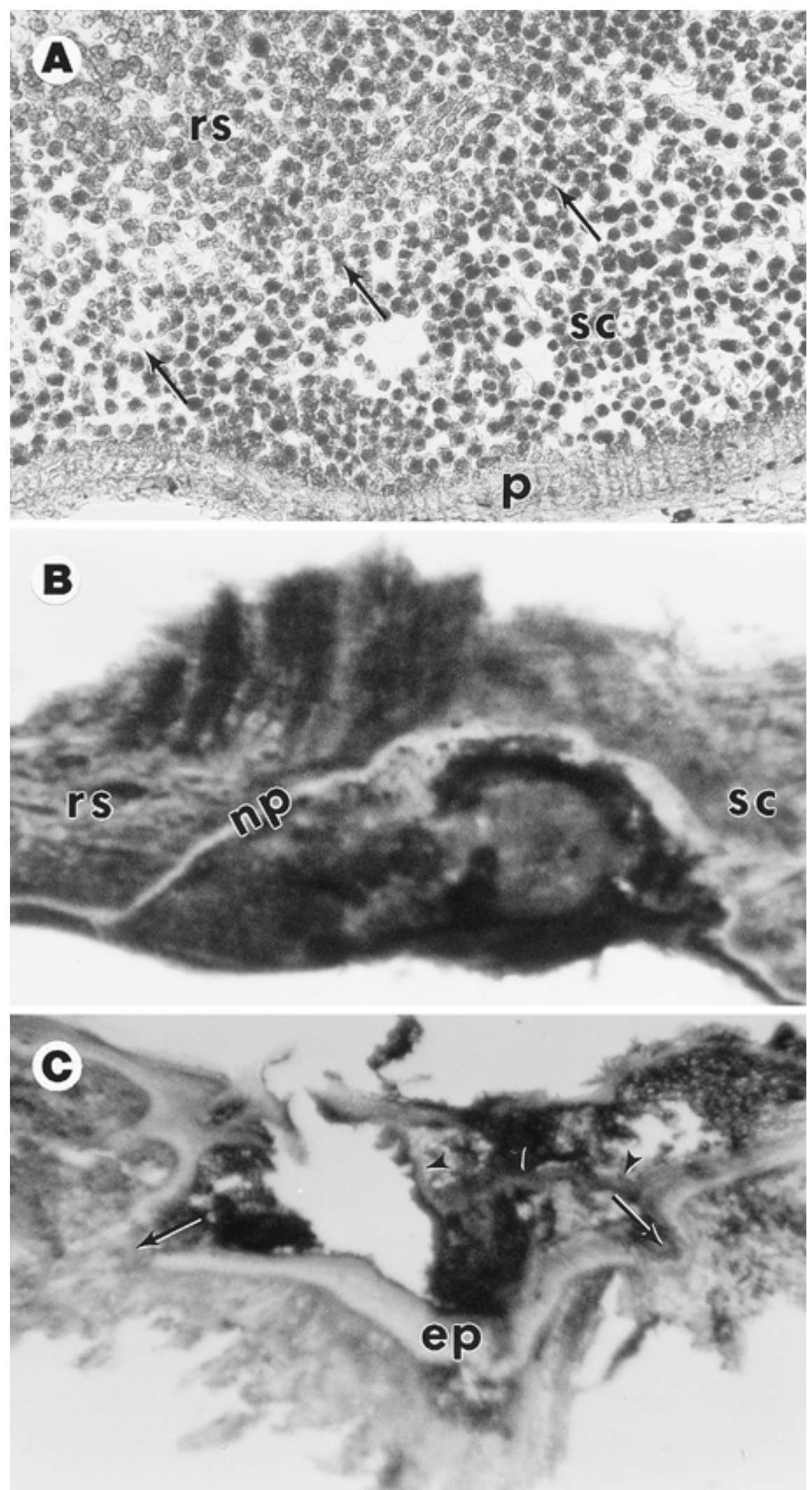

Fig. 2. (A) Light micrographs of bark tissue at graft union from healthy Stanley/Myrobalan 29C plum tree. Union area of scion (sc) and rootstock (rs) is indicated by arrows. p = periderm. (40x) (BC) Radial longitudinal sections through brown line (BL) region of 70031/Marianna 4001 plum. (B) Early stage of wound response process. Elliptical region is $3 \mathrm{~mm}$ long and $1 \mathrm{~mm}$ thick. $\mathrm{np}=$ necrophylactic periderm. (30x) (C) Advanced stage in wound response process. Note disruption of wound tissue and infolding of associated wound periderm layers (arrows). Also note compartmentalization (arrowheads) inside wound tissue. Wound region was $3.5 \mathrm{~mm}$ long and $1.5 \mathrm{~mm}$ thick. ep = exophylactic periderm. $(40 x)$ 
Statistical analysis of the immunolabel. Nine tissue blocks from a ToRSVpositive, PBL-exhibiting 70031/Marianna 4001, one block from a ToRSV positive, non-PBL-exhibiting Stanley/Myrobalan 29C, and four blocks from a noninoculated, healthy Stanley/Myrobalan 29C plum tree were sectioned and immunolabeled. Three blocks each of ToRSV inoculated and noninoculated rootstock sucker leaf tissue were also sectioned and labeled. The silver-enhanced gold particles on the cell wall and in the cytoplasm were counted on both the infected and control tissue sections. Counts were obtained from at least one tissue section per block. The data obtained were subjected to a one-way analysis of variance (ANOVA) for a completely randomized design (8) to determine whether the differences in labeling between diseased and healthy tissues were statistically significant.

\section{RESULTS}

Anatomical study of BL. A view of the BL disease in a symptomatic tree is shown in Figure 1. Systemic rootstock infection by ToRSV in the plum tree triggered a host response that resulted in wound areas in the bark demarcated by purple and pinkish purple necrophylactic periderms. Gray and yellowish gray exophylactic periderm layers surrounding the wound tissue and underlying the necrophylactic periderm were also observed. In contrast to the above results, observation of a healthy graft union revealed smooth, contiguous bark tissue between the rootstock and the scion (Fig. 2A). The periderm was yellowish gray in color. The type of anatomical changes in the BL area may be grouped into two categories: an early stage (Fig. 2B) and an advanced stage (Fig. 2C) in the wound response process. In both stages, the BL region was highly pigmented with black, gray, dark brown, purple, and pinkish purple pigments. The wound areas were elliptical in shape in the early stages of the wound response process (Fig. 2B). The cells in the wound tissue were mostly thin walled and rectangular in radial sections. There were compartments lined with necrophylactic periderms within an area of wound tissue, and it was not uncommon to find an elliptical area nested within a larger elliptical area. Sometimes two distant elliptical regions were connected by layers of necrophylactic periderms. Early stages of the wound response process were seen in 70031/Marianna 4001 (Fig. 2B).

In an advanced stage of the wound response process, there was disruption of tissue internal to the wound periderm (Fig. 2C). The wall of the ellipse toward the outside of the tree had broken open, and there was collapse of cells within, resulting in patches of cells and open spaces. Traces of purple and pinkish purple pigments could be observed. The exophylactic periderm layers of the ellipse, toward the
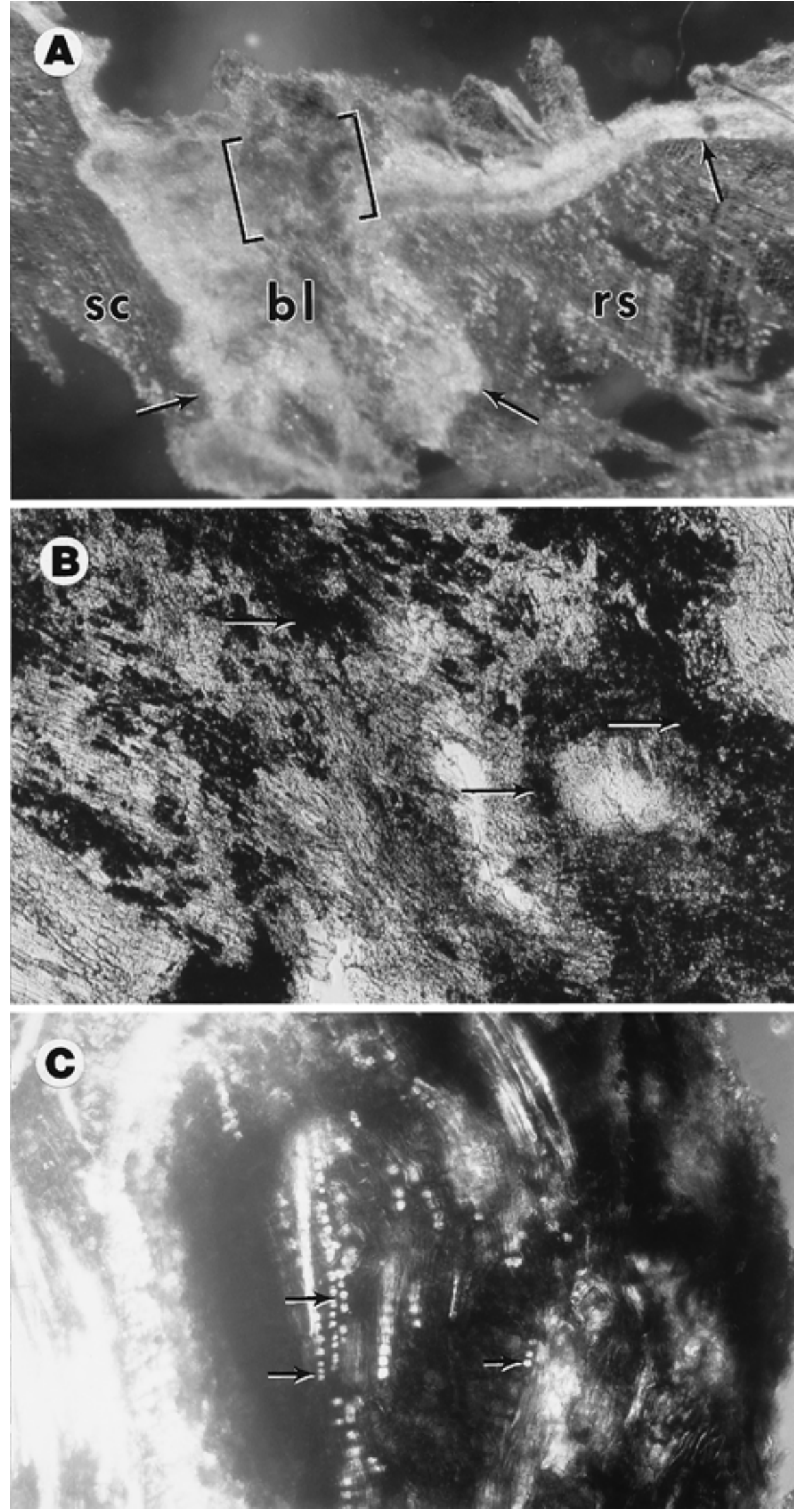

Fig. 3. (A) Radial longitudinal section through brown line (BL) region of 70031/Myrobalan 29C plum in advanced stage of wound response. Necrotic cells of BL region are outlined (arrows) in this darkfield image. Note that BL (5 mm long and $2 \mathrm{~mm}$ wide) is spread in entire width of sample. $\mathrm{sc}=$ scion, $\mathrm{rs}=$ rootstock, $\mathrm{bl}=$ brown line. $(27 \times)(\mathbf{B})$ Higher magnification image of boxed area in $\mathrm{A}$ Cells in wound response tissue have collapsed, and black debris (arrows) denoting weathering of dead and collapsed cells can be seen. (88x) (C) Plane polarized image of radial longitudinal section through BL region of 70031/Marianna 4001 plum tree. Fully crossed polars reveal presence of druse crystals (arrows) in wound response tissue of BL region. (70×) 

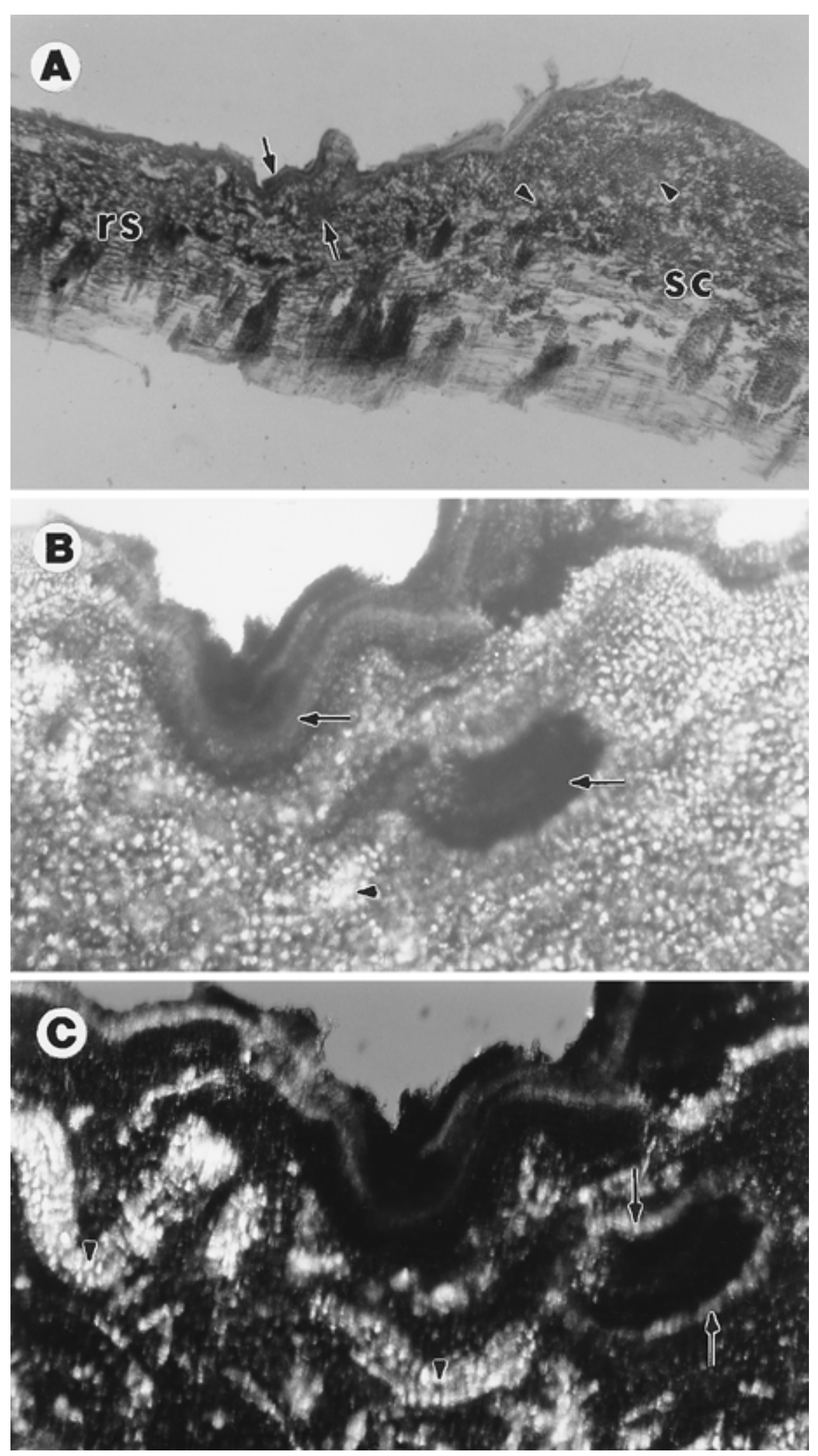

Fig. 4. (A) Radial longitudinal section through graft union (arrowheads) of Stanley/Myrobalan 29C plum tree. Rootstock tested tomato ringspot virus-positive but brown line-absent. Note that the two wound response areas are in rootstock of graft (arrows). $\mathrm{sc}=$ scion, $\mathrm{rs}=$ rootstock. (7x) (B) Higher magnification image of wound response regions (arrows) in A. Discolored, nonpurple pigmented region further down in rootstock is denoted by arrowhead. (66×) (C) Plane polarized image of wound response area in B. Fully crossed polars show birefringence of cell layer on outside of wound response (arrows). Note two crescent areas of cells polarizing (arrowheads). Birefringent cells seen in crescent areas are probably phellogen activity marker cells. This suggests that it is the site of wound response activity next in sequence. Compare with B. (56×) inside of the tree, were several layers thicker than was the case when the ellipse was intact, with relatively fewer layers of necrophylactic periderm. Seen in transverse sections were the necrophylactic and wavy exophylactic periderms (Fig. 3A) and the disintegration of cells in the wound tissue (Fig. 3B). Layers of pinkish purple tissue were seen alternating with greenish brown tissue layers, suggesting the presence or formation of necrophylactic periderm layers that would compartmentalize the wound tissue. The outline of the wound response area was now wavy and irregular rather than curved (Fig. 3A). The periderm layers were pocketing inward, and it appeared as if the BL had been spreading inward and toward the central axis of the plum tree at the time of sampling (Fig. 3A). The cells beneath the pocketing periderm toward the inside of the tree were discolored. It was not possible to distinguish the graft union due to the disruption in the tissue of the graft union region. Bark samples in the advanced stages of the wound response process were observed in 70031/Marianna 4001 (Fig. 2C) and 70031/Myrobalan 29C plum trees (Figs. 3A and 3B). Druse crystals arranged in rows were observed in the $\mathrm{BL}$ regions of 70031/Marianna 4001 (Fig. 3C) and 70031/Myrobalan 29C plum trees. Druse crystals were observed in the cortex of the healthy graft union but not in the periderm or the secondary layers close to the periderm.

Initial stages in $\mathrm{BL}$ formation. Initial stages in the process of BL formation in bark can be studied by observing bark samples from the graft union of a Stanley/Myrobalan 29C plum tree that did not have a visible $\mathrm{BL}$ but had roots that tested ToRSV-positive by ELISA. Crescent shaped, localized patches, $1 \mathrm{~mm}$ in length, were seen in the bark below the periderm (Fig. 4A and B, higher magnification). The cells in this area polarized light and contained purple and pinkish purple pigments. This is the start of necrophylactic periderm formation. Sudan IV was used in addition to polarization to confirm the identity of periderm tissues and suberized cells within the periderm. Further down this area and into the rootstock, there were two crescent shaped lighter colored regions (arrowheads, Figs. 4B and C). The crescent shaped, nonpurple pigmented tissue in these two regions also polarized light. The birefringent cells seen in the crescent shaped areas are probably phellogen activity marker cells, suggesting that these two regions are in a process of wound response and will form the purple necrophylactic periderms (Fig. 4C). It is likely that these regions may join together and form the ellipse that is characteristic of the early wound response process in the $\mathrm{BL}$ region. Thus, it may be said that in the process of BL formation, wound response processes in the plum tree generate areas of wound 
tissue demarcated by wound periderms. These areas start at a point in the rootstock at or near the graft union and may coalesce and spread further downward into the rootstock and away from the scion.

Immunolabeling. ToRSV was immunolocalized in the bark of the $\mathrm{BL}$ region of 70031/Marianna 4001 (Fig. 5B) and Valor/St. Julian 655-2 plum. The virus was also immuno-localized in Marianna 4001, St. Julian 655-2, and Myrobalan 29C rootstocks (Fig. 5D) and in the scion 70031 (Fig. 5F). Labeling was observed on the cell wall and in cytoplasm of the cells, with a major portion of the label on the cell wall. A major portion of the label in the bark was observed in the secondary phloem parenchyma, with the least labeling in the periderm layers. Heavier labeling was seen in the axial phloem than in the radial phloem (Fig. 5D). Labeling was not seen on the BL bark samples when preimmune serum was substituted for ToRSV serum (Fig. 5C). Insignificant, sparse labeling occurred with healthy rootstock bark sample (Fig. 5E). Significant labeling occurred with rootstock sucker leaf sample (Fig. 5G). Bundle sheath cells were heavily labeled, while xylem tissue was sparsely labeled (Fig. 5G). Statistically insignificant labeling occurred on a healthy rootstock sucker leaf sample (Fig. 5H).

Statistical analysis. The $F$ value for the statistical analysis of the labeling on the $\mathrm{BL}$ rootstock bark samples and on the healthy rootstock bark samples showed significant differences $(P=0.01)$ between the two. The $F$ value in the comparison of the labeling on bark of the scion 70031 and bark of the rootstock, Myrobalan 29C, versus healthy rootstock bark tissue was significant at $P=0.01$. The $F$ value in case of the plum rootstock sucker leaf sample was statistically significant at $P=0.01$.

\section{DISCUSSION}

Defense response of the plant: Formation of the BL. Plants respond in a nonspecific manner to a variety of factors that disrupt the integrity of the system. The factors that elicit the defense response may be injuries due to insects, rodents, birds, wounds, or infection by pathogens such as nematodes, virus, fungi, and bacteria $(1,11)$. Work by Mullick (10) has shown that nonsuberized impervious tissue (NIT) and necrophylactic periderm formation occur in the bark of uninjured and injured woody conifers as a nonspecific host response. Since ToRSV was immuno-localized in the bark tissue at the BL area, and also in the scion and rootstock tissue immediately above and below the BL, respectively, it may be assumed that the histopathological changes seen were due to infection by ToRSV. In demarcating elliptical areas of wound tissue with necrophylactic periderm, the plum tree responded in a nonspecific manner. After such a demarcation has occurred, it is expected that a normal exophylactic periderm would form, separating the wound tissue from the inside of the plant, and later on causing a sloughing off of all the layers that it separates from the intact plant tissue. This would normally be expected to be the end of all apparent signs of infection having ever taken place in the plant. However, even as the wound tissue is being sloughed off, some unknown changes in the plant, presumably caused by continued viral activity, resulted in spread of the periderm inward. The periderm appeared wavy in outline with the trough of the wave spreading inward. There were discontinuities in the periderm, thus creating channels between the cells inside and the cells formerly enclosed by the periderm. As the periderm spread inward at several points, it continued to elicit the host defense mechanism and stimulated the formation of a necrophylactic periderm. At this stage, the BL developed not only inward but also in a circumferential fashion.

The histopathological changes seen in the bark of Stanley/Myrobalan 29C showed a polarizing layer of tissue, internal to which purple necrophylactic periderm layers had developed. The polarizing nature of the purple necrophylactic periderm cells and the exophylactic periderm cells was shown by Mullick and Jensen (12). The cells in the necrophylactic periderm are filled with a luminous fluid that makes it difficult to detect polarization. When the contents of the cells have dissipated, the cell outline was more clearly evident. This may be why polarized cells were observed as an outline of the wound area. Polarized light also revealed two crescent areas in the rootstock that had not yet developed a purple pigmentation. The polarizing nature of these cells suggests they are an impervious tissue zone and will most likely develop the purple necrophylactic periderm internally. When a number of such areas with wound response symptoms are seen along the circumference of the bark, they may join together, either by merging or through strips of necrophylactic periderm connections and result in a continuous zone of necrotic tissue, referred to as brown line. In a study of apple union necrosis disease (AUND) (15), the authors suggested that the symptoms progress from an intermittent pitting to a continuous row of pits to a necrotic layer of tissue. The formation of the $\mathrm{BL}$ in the PBL disease may occur in a similar manner, with discrete points of necrosis joining to result in a complete brown line that extends the entire circumference and weakens the graft union. In such a weakened state, the tree would be susceptible to winter injury. Winter injury in PBL-diseased plum and prune trees has been reported by Brase and Parker (2), Kirkpatrick et al. (7), and Mircetich and Hoy (9). The inwardly spreading BL also creates portals of entry for secondary pathogens, such as fungi and bacteria, that may further debilitate the tree. The presence of druse crystals in the $\mathrm{BL}$ region suggests the possibility of a fungal infection of this area. A hypothesis has been proposed that oxalic acid produced by cell wall degrading fungi, such as $S$. rolfsii during pathogenesis in sugar beet and carrot leaf tissue sequesters calcium, is a byproduct of cell wall degradation and results in the formation of calcium oxalate crystals (13). On the other hand, the druse crystals may be storing the calcium reserves necessary for the dedifferentiation and redifferentiation of cells and the formation of secondary meristems (4) and subsequently the necrophylactic periderm.

Hypothesis for PBL disease. Hoy and Mircetich (6) reported that PBL results from a hypersensitive reaction of a resistant scion to ToRSV infection in a susceptible rootstock. Immunolabeling results from our study show that the plum scion 70031 is susceptible to ToRSV infection. ToRSV was detected in the scion tissue in two of 32 Stanley propagated on ToRSVinfected rootstocks (3). Flame reaction of the dead tissue in Stanley, extending up to $2.5 \mathrm{~cm}$ above the union (3), suggests that there is an interplay between ToRSV and the scion. Wound tissue surrounded by necrophylactic periderm was noticed in the BL region, with necrophylactic periderm strips progressing into the scion, apparently from the rootstock at the graft union. This observation suggests that the BL is indeed a result of a hypersensitive reaction. However, it is not clear that the $\mathrm{BL}$ is the result of a hypersensitive response from the scion. The anatomical changes suggest that it is more likely the result of a hypersensitive response from the rootstock.

In our study, the histopathological observations made on the graft union bark tissue of Stanley/Myrobalan 29C (Fig. 4, the ToRSV-positive but BL-negative tree) suggest that the BL symptoms are initiated in the rootstock region of the graft union. The elliptical BL regions seen in 70031/Marianna 4001 (Fig. 2B) also suggest that the BL starts in the rootstock or at the graft union (scion/stock) interface, but not in the scion. However, since it is not certain that the symptoms of the BL started at the scion/stock interface in an advanced stage wound response, it cannot be stated absolutely whether the hypersensitive response is elicited by the scion or the rootstock. It is likely that the BL may be a result of the activities in both the scion and the rootstock, and the BL response could be triggered by diffusion from one to the other of some chemical induced by the ToRSV infection. The results of this study suggest PBL is a result of a hypersensitive response to ToRSV infection in a rootstock. A hypersensitive response in woody plants may be very different from that in herbaceous plants. In woody plants, changes associated with hypersensitive 

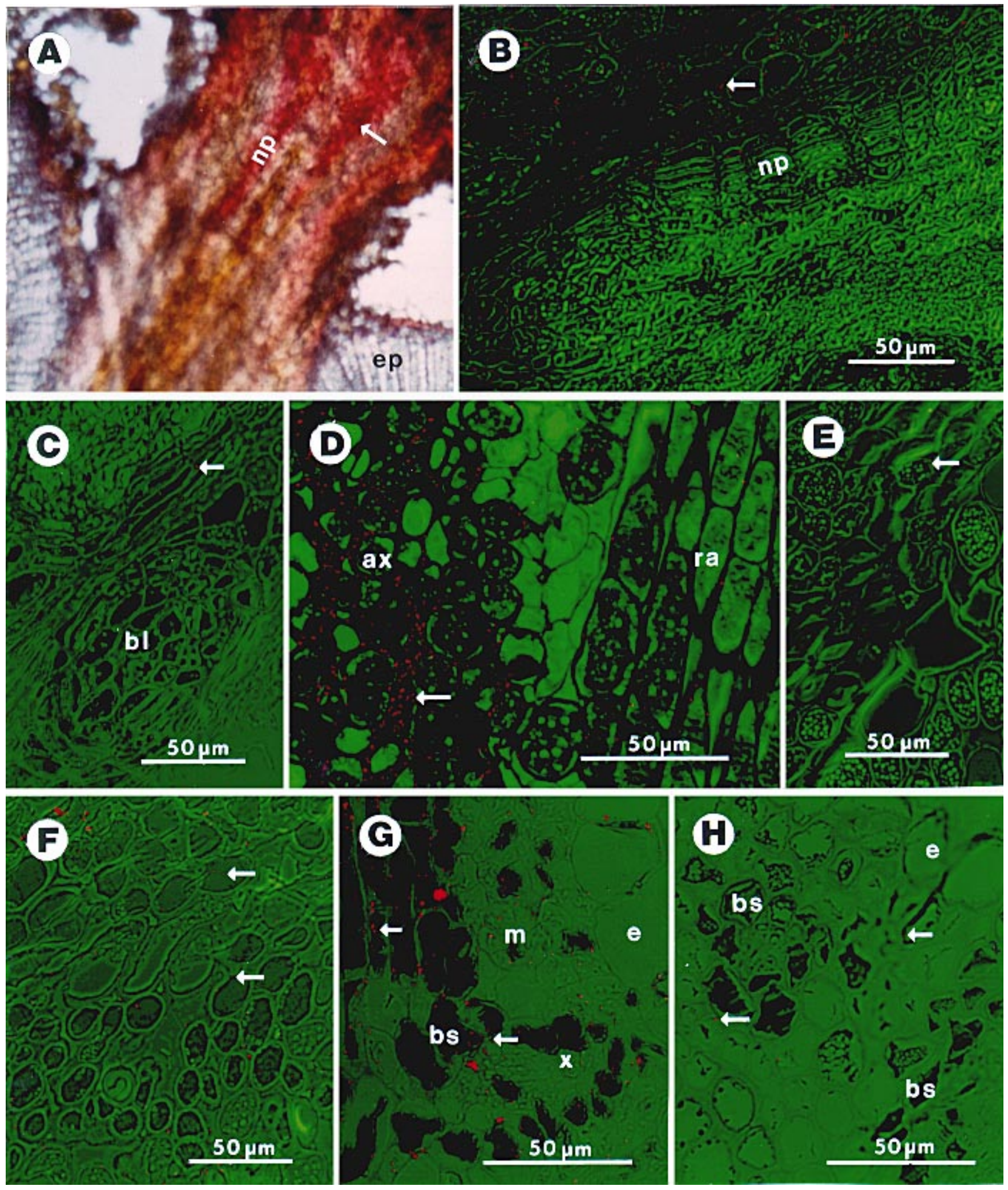

Fig. 5. (A) Transverse section through brown line (BL) region of 70031/Myrobalan 29C plum tree in advanced stage of wound response. Pinkish purple pigments appear reddish purple due to print quality. Note reddish purple pigmentation (arrow), suggesting presence of necrophylactic periderm (np). More than one layer of necrophylactic periderm pigments denotes compartmentalization of wound tissue. Position of sequent exophylactic periderm (ep) suggests its formation resulted after several layers of necrophylactic periderm activity. (55x) (B-G) Light microscopy immunolabeling. (B) BL region of 70031/Marianna 4001 plum. Silver-enhanced gold labeling (arrow) is seen as red and yellow reflected image on green transmitted image. Note sparse labeling of necrophylactic periderm layers and significant labeling on walls of most secondary phloem cells and in cytoplasm of some secondary phloem cells (arrow). Sectioning was done through elliptical region in Figure 2B. (C) BL bark of 70031/Marianna 4001 plum labeled with preimmune serum. Note insignificant labeling (arrow). bl = brown line area. (D) Rootstock bark from tomato ringspot virus (ToRSV)-inoculated Stanley/Myrobalan 29C plum tree. Note heavy labeling (arrow) on axial (ax) component of secondary phloem compared with light labeling on radial (ra) component. (E) Rootstock bark from healthy Stanley/Myrobalan 29C plum tree. Note statistically nonsignificant labeling (arrow). (F) Scion bark from 70031/Marianna 4001 plum. Note silver-enhanced protein A-gold label (arrow) on cell wall and in cytoplasm. (G) Rootstock sucker leaf of ToRSVinoculated Stanley/Myrobalan 29C plum. Note a significant amount of silver-enhanced gold label (arrows) in the bundle sheath (bs) parenchyma cells. e = epidermis, $\mathrm{m}=$ mesophyll, $\mathrm{x}=$ xylem. $(\mathbf{H})$ Rootstock sucker leaf of healthy Stanley/Myrobalan 29C plum. Note statistically nonsignificant labeling (arrow). 
response may not take place as rapidly as in herbaceous plants, where cell death occurs within hours of infection. In virusinduced HR, even though necrosis develops, cell death may be at a rate too slow to prevent local lesion size increase, and thus systemic spread of the virus results (5). The ToRSV-induced HR in the plum rootstock appears to be at a rate that permits the replication and systemic movement of the virus. The cultivars appear to have a role in the various symptoms that are associated with PBL, as evidenced by the overgrowth of the scion at the graft union (2). Statistical analysis comparing the scions 70031, Valor, and Stanley shows that there are significant differences between 70031 and the other two scions in predisposing the rootstock to PBL disease. Further results from the study in Traverse City may help elucidate the role played by the scion in PBL development.

\section{LITERATURE CITED}

1. Bostock, R. M., and Stermer, B. A. 1989. Perspectives on wound healing in resistance to pathogens. Annu. Rev. Phytopathol. 27:343-371.

2. Brase, K. D., and Parker, K. G. 1955. Decline of Stanley prune trees. Plant Dis. Rep.
39:358-362.

3. Cummins, J. N., and Gonsalves, D. 1986. Constriction and decline of 'Stanley' prune associated with tomato ringspot virus. J. Am. Soc. Hortic. Sci. 111:315-318.

4. Francheschi, V. R., and Horner, H. T., Jr. 1980. Calcium oxalate crystals in plants. Bot. Rev. 46:361-427.

5. Goodman, R. N., and Novacky, A. J. 1994. The Hypersensitive Reaction in Plants to Pathogens: A Resistance Phenomenon. American Phytopathological Society, St. Paul, $\mathrm{MN}$.

6. Hoy, J. W., and Mircetich, S. M. 1984. Prune brownline disease: Susceptibility of prune rootstocks and tomato ringspot virus detection. Phytopathology 74:272-276.

7. Kirkpatrick, J. D., Parker, K. G., and Fisher, E. G. 1958. Decline of Stanley plum accentuated by winter injury. Plant Dis. Rep. 42:6570 .

8. Little, T. M., and Hills, F. J., eds. 1975. Analysis of counts. Pages 193-198 in: Statistical Methods in Agricultural Research. University of California, Davis.

9. Mircetich, S. M., and Hoy, J. W. 1981. Brownline of prune trees, a disease associated with tomato ringspot virus infection of Myrobalan and peach rootstocks. Phytopathology 71:30-35.

10. Mullick, D. B. 1975. A new tissue essential to necrophylactic periderm formation in the bark of four conifers. (Studies on periderm. VI) Can. J. Bot. 53:2443-2457.
11. Mullick, D. B. 1976. The non-specific nature of defense in bark and wood during wounding, insect and pathogen attack. (Studies on periderm. IX) Recent Adv. Phytochem. 11:395-442.

12. Mullick, D. B., and Jensen, G. D. 1973. Cryofixation reveals uniqueness of reddish-purple sequent periderm and equivalence between brown first and brown sequent periderms of three conifers. (Studies on periderm. IV) Can. J. Bot. 51:135-143.

13. Punja, Z. K., and Jenkins, S. F. 1984. Light and scanning electron microscopic observations of calcium oxalate crystals produced during growth of Sclerotium rolfsii in culture and in infected tissue. Can. J. Bot. 62:20282032.

14. Ramsdell, D. C., Adler, V. A., and Kesner, C. R. 1993. Prune brown line disease occurrence in declining 'Stanley' plum orchards in Michigan and factors related to its incidence. Hort Technol. 3:325-329.

15. Rosenberger, D. A., Harrison, M. B., and Gonsalves, D. 1983. Incidence of apple union necrosis and decline, tomato ringspot virus, and Xiphinema vector species in Hudson Valley orchards. Plant Dis. 67:356-360.

16. Stace-Smith, R. 1966. Purification and properties of tomato ringspot virus and an RNA deficient component. Virology 29:240-247.

17. Vandenbosch, K. A. 1991. Immunogold labeling. Pages 181-218 in: Electron Microscopy of Plant Cells. J. L. Hall and C. Hawes, eds. Academic Press, San Diego, CA. 